\title{
Application of Adsorption and Immobilization Techniques to Reduce Hexavalent Chromium Pollution using Banana Peels Residual Biomass as Biosorbent
}

\author{
Angel Villabona-Ortiz', Candelaria Tejada-Tovar', Angel Gonzalez-Delgado ${ }^{*}$, \\ Erika Ruiz-Paternina' and Nórida Pájaro-Gómez' \\ 'Department of Chemical Engineering, Process Design and Biomass Utilization Research \\ Group (IDAB), University of Cartagena, Cartagena, Bolivar, Colombia; \\ avillabonao@unicartagena.edu.co, ctejadat@unicartagena.edu.co, \\ eribeatriz0925@hotmail.com, norida66@gmail.com \\ ${ }^{2}$ Nanomaterials and Computer Aided Process Engineering Research Group (NIPAC), \\ University of Cartagena, Cartagena, Bolivar, Colombia; \\ agonzalezd1@unicartagena.edu.co
}

\begin{abstract}
Background: Contamination with heavy metal ions has been recognized an important issue that require alternatives to be faced. Adsorption is considered a promising technique to remove these pollutants from aqueous solution. However, disposal problems of polluted biomass have limited its application. Objective: In this work, banana peels biomass is employed as biosorbent for hexavalent chromium uptake. Methods/Statistical Analysis: The effects of particle size, temperature and dosage were considered during adsorption batch experiments. Sorption-desorption cycles were performed in order to analyze the biosorbent useful life. To solve biomass disposal problems, solidification/stabilization immobilization technique was used for heavy metal ions encapsulation through bricks preparation. These bricks were subjected to mechanical resistance and leaching tests to identify if they obey quality and environmental standard. Findings: Results revealed that biosorbent dosage was the parameter that most contributed adsorption process. After sorption-desorption cycles, the biosorbent reduced its removal capacity by 30\%. Application/Improvements: The mechanical resistance and leaching tests suggested the applicability of residual biosorbent for preparing bricks due to the low leachate concentration and high compression resistance.
\end{abstract}

Keywords: Adsorption, Biomass, Desorption, Heavy Metals, Immobilization

\section{Introduction}

Several heavy metals have been discharged into the environment by industrial activities worldwide. Hexavalent chromium is considered one of the most common pollutant because of its wide applicability 1 . This heavy metal is employed in many industries as electroplating, paints, pigments, textile dyeing and tanning 2 . Chromium represents a major health concern in marine ecosystems because it is non-biodegradable and highly toxic ${ }^{3}$. To face this environmental issue, researchers have focused their attention on the development of suitable removal methods including ion exchange, chemical precipitation and adsorption. The advantages

${ }^{*}$ Author for correspondence 
that adsorption technique offers (efficiency, low cost and ease of operation) have allowed to identify this method as a promising solution for heavy metal pollution ${ }^{4}$. One of the main limitations for adsorption application is the disposal problem of adsorbent material after sorptiondesorption cycles, hence, many works have proposed the use of heavy metal encapsulation technologies such as solidification/stabilization immobilization, which reduce the potential migration of these pollutants in the waste ${ }^{5}$.

Biomass from agricultural wastes are widely employed for preparing adsorbents due to its effectiveness and availability ${ }^{6}$. In addition, disposal problems are reduced as well as the attraction of air or vector-borne diseases ${ }^{7}$. Biomaterials as almond hull, pecan shells, rice, lemon peels and cassava peels are tested in adsorption processes $\stackrel{8}{2}$. Among these, banana peels are attractive source of biomass due to the huge amount wasted every year ${ }^{10}$. The peels represent about $35 \%$ of the whole fruit weight, hence, it is advantageous to add value to a waste while environmental problems are solved ${ }^{11}$. In this work, banana peels biomass was used to remove hexavalent chromium ions from aqueous solution. After sorption-desorption cycles, the residual biosorbent was subjected to solidification/stabilization technique to encapsulate the pollutants.

\section{Materials and Methods}

\subsection{Biomass Preparation}

In brief, the banana peels biomass was washed with distillate water in order to remove adhered particles that can affect adsorption process. The resulting material was dried for $24 \mathrm{~h}$ at $60^{\circ} \mathrm{C}$ for further particle size reduction procedure. It was selected different particle sizes (1, 0.5 and $0.355 \mathrm{~mm}$ ) to evaluate the effect of this parameter on adsorption process, which were obtained by grounding and sieve-meshing ${ }^{12}$. The functional groups in biomass surface were identified by Fourier-Transform Infrared Spectroscopy (FT-IR) before and after hexavalent chromium uptake.

\subsection{Adsorption Batch Experiments}

The adsorption experiments were carried out by mixing $\mathrm{K}_{2} \mathrm{Cr}_{2} \mathrm{O}_{7}$ into deionized water to achieve a 100 ppm solution. The solution $\mathrm{pH}$ was adjusted using
$\mathrm{HCl}$ and $\mathrm{NaOH}$ solutions as reported by ${ }^{13}$. The effect of temperature, particle size and biosorbent dosage was assessed with the aim of identifying suitable conditions for performing adsorption process. The temperature was varied in 40,55 and $70^{\circ} \mathrm{C}$. The values for biosorbent dosage were $0.15,0.325$ and $0.5 \mathrm{~g}$. The contact time as well as stirring was fixed in $5 \mathrm{~h}$ and $200 \mathrm{rpm}$, respectively. Adsorption kinetics was studied under two different conditions for particle size $(0.355$ and $0.5 \mathrm{~mm})$, biosorbent dosage $(0.5$ and $0.67 \mathrm{~g})$ and temperature $\left(25\right.$ and $\left.40^{\circ} \mathrm{C}\right)$.

\subsection{Sorption-Desorption Cycles}

After adsorption batch experiments, biomass was filtered and mixed with $1 \mathrm{M}$ nitric acid that was selected as desorbing agent. Desorption cycles were performed in a stirring plate under room temperature during $3 \mathrm{~h}^{\underline{14}}$. The resulting biomass was filtered and washed before regeneration process using calcium chloride at $4^{\circ} \mathrm{C}$ for $12 \mathrm{~h}$. The regenerated biosorbent was filtered and dried to start the following sorption-desorption cycle ${ }^{15}$.

\subsection{Solidification/Stabilization Immobilization Technique}

The dried residual biomass after several sorption-desorption cycles was used to prepare bricks using clay. The composition of biomass in bricks was varied in $5,7.5$ and $10 \%$ to study the influence of polluted biosorbent on achieving quality and environmental standards. The mixture of clay and biomass was heated at $70^{\circ} \mathrm{C}$ for $24 \mathrm{~h}$. Then, it was sent to a muffle at $800^{\circ} \mathrm{C}$ for $3 \mathrm{~h}$ in order to obtain compact bricks ${ }^{16}$. The mechanical resistance of these bricks was determined according to the methodology proposed by Ukwatta and Mohajerani ${ }^{17}$. Leaching tests were also performed to determine the applicability of this technique obeying environmental regulation. A bricks sample was collected and added to $96.5 \mathrm{~mL}$ of distillate water. Then, $\mathrm{pH}$ was measured and adjusted below 5 using $\mathrm{HCl}$ solution in order to identify the extraction fluid used in these tests ${ }^{17}$. To prepare the extraction fluid, $5.7 \mathrm{~mL}$ of acetic acid was added in $1000 \mathrm{~mL}$ of water. The leaching experiments were performed by mixing $1 \mathrm{~g}$ of bricks with $20 \mathrm{~mL}$ of extraction fluid under continuous stirring (30 rpm) for $18 \mathrm{~h}$, followed by filtration. 


\section{Results and Discussion}

\subsection{Biomass Characterization}

Figure 1 shows the spectrum of banana peels before and after adsorption process in order to identify functional groups affecting chromium ions uptake. It was observed absorption bands around 3600 and $1748 \mathrm{~cm}^{-1}$ assigned to hydroxyl and carbonyl groups, respectively, which are widely found in the chemical composition of lignocellulosic materials $\frac{18}{}$. After adsorption process, variations in the spectrum are observed around 1000-1800 $\mathrm{cm}^{-1}$ confirming the contribution of carbonyl groups. As shown in Figure 2, the stretching of absorption band at $3600 \mathrm{~cm}^{-1}$ suggested the interaction of hydroxyl groups with $\mathrm{Cr}(\mathrm{VI})$ ions $^{\underline{13}}$.

\subsection{Adsorption Experiments}

\subsubsection{Effect of Particle Size}

The influence of particle size on adsorption process was studied by varying particle size in $0.355,0.5$ and 1 $\mathrm{mm}$. As shown in Figure 3, this parameter did not affect significantly the chromium ions uptake. It is well known

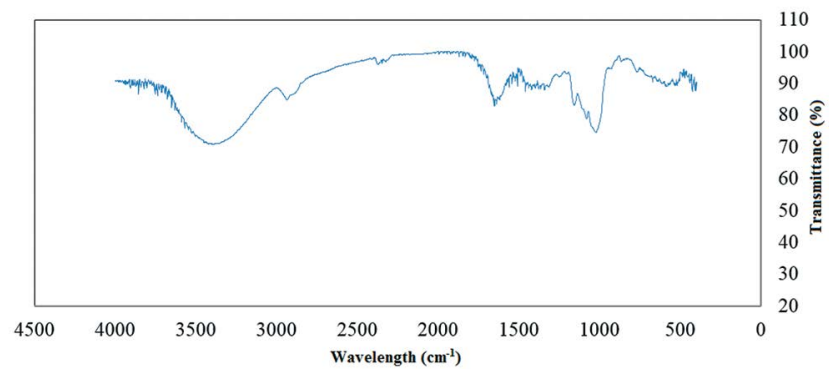

Figure 1. FT-IR spectrum of banana peels biomass.

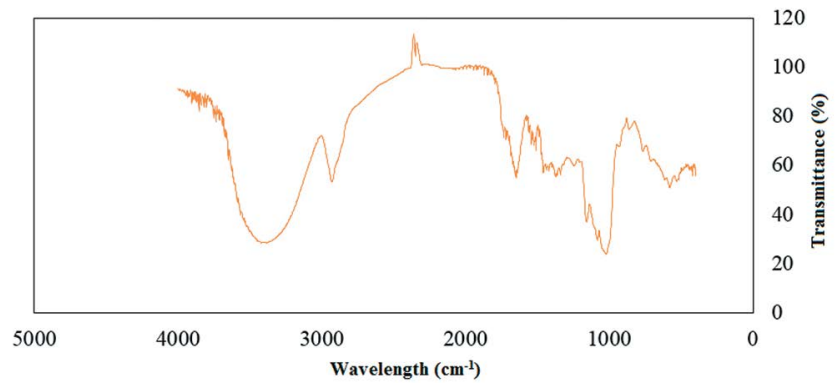

Figure 2. FT-IR spectrum of banana peels biomass after chromium uptake. that small particles exhibit high removal yield because of the increase in active sites. However, the porous capacity may not depend on particle size causing slight variation of adsorption results ${ }^{19}$. Figure 4 shows the adsorption results over different temperature conditions between 40 and $70^{\circ} \mathrm{C}$. It was found that this parameter did not influence chromium removal and its increases were not significant over temperature variations. The biosorbent dosage was the parameter that most affected removal yields. As shown in Figure 5, the chromium uptake increased as

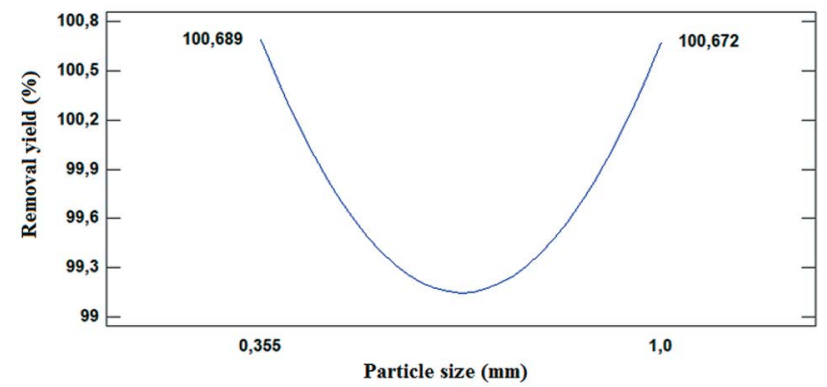

Figure 3. Effect of particle size on Cr (VI) ions removal yield.

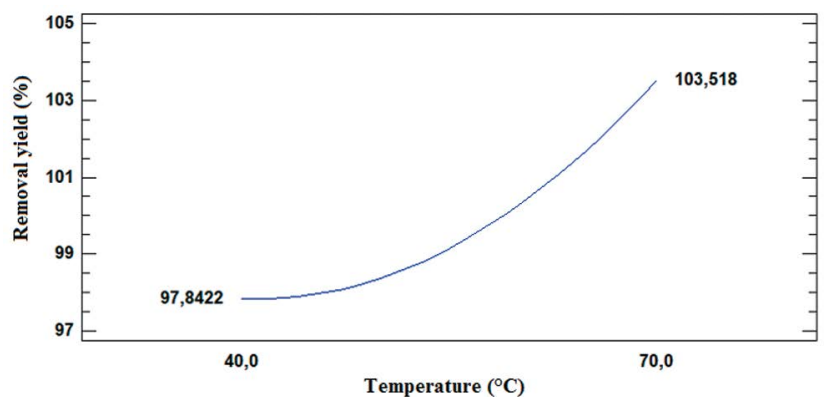

Figure 4. Effect of temperature on Cr (VI) ions removal yield.

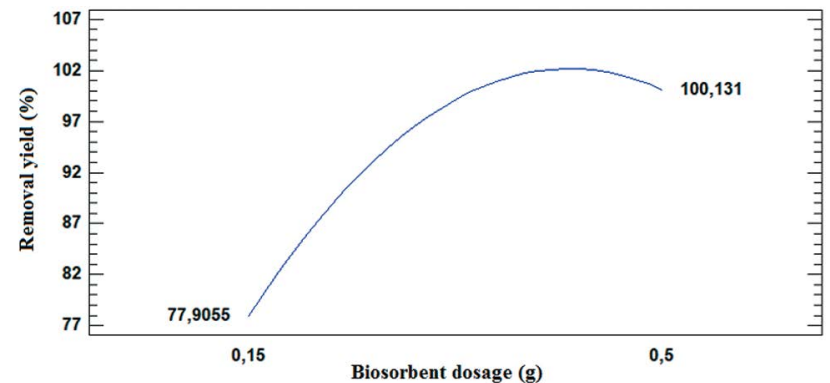

Figure 5. Effect of biosorbent dosage on $\mathrm{Cr}$ (VI) ions removal yield. 
biosorbent dosage increased due to the presence of more active sites. These results were confirmed by applying Pareto chart shown in Figure 6. As can be observed, the parameter that most contributed to adsorption process was biomass dosage, followed by temperature and particle size ${ }^{20}$ pointed out that increasing biomass amount enhances heavy metal ions uptake because of the increase in available active sites.

\subsubsection{Adsorption Kinetics}

Figure 7 shows the adsorption kinetics considering two different operating conditions that include variations in particle size, biosorbent dosage and temperature. The small-sized particles $(0.355 \mathrm{~mm})$ exhibited the highest adsorption at the beginning, similar removal yields were achieved more quickly using particle size of $0.5 \mathrm{~mm}$. Hence, it was selected the following values for temperature, particle size and biosorbent dosage: $25^{\circ} \mathrm{C}$, $0.5 \mathrm{~mm}$ and $0.67 \mathrm{~g}$, respectively.

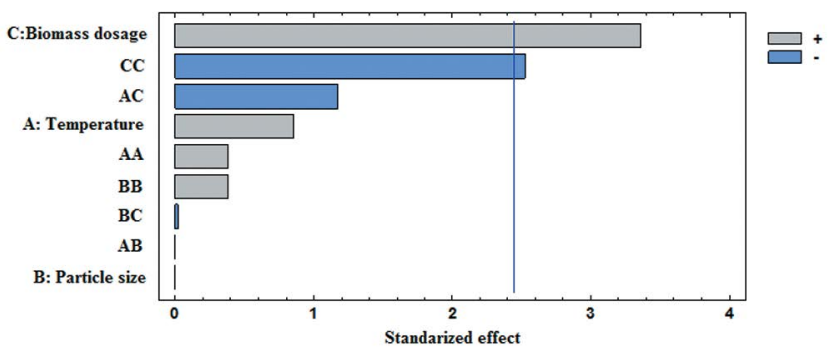

Figure 6. Pareto chart of adsorption parameters.

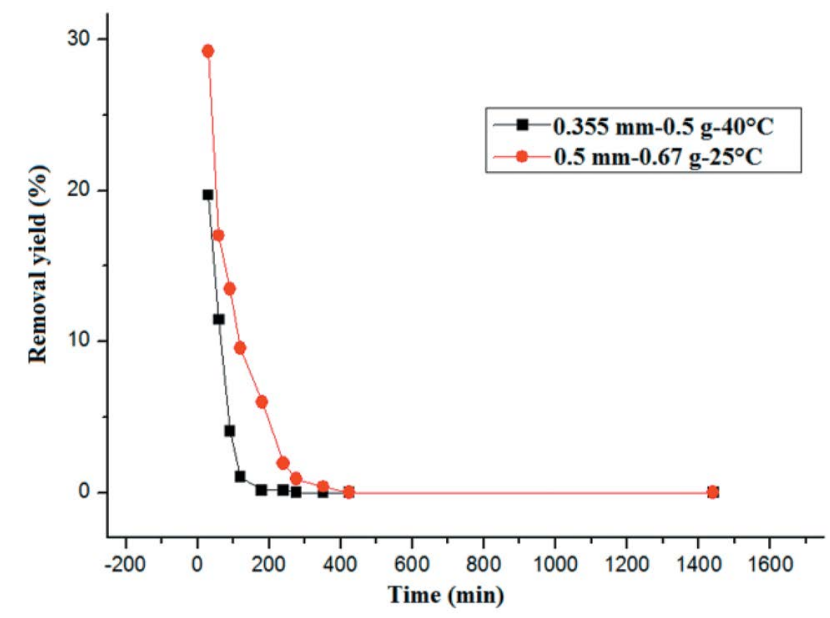

Figure 7. Adsorption kinetics results using banana peels for $\mathrm{Cr}(\mathrm{VI})$ ions uptake.

\subsection{Adsorption-Desorption Cycles}

As shown in Figure 8, banana peels biomass exhibited a reduction in adsorption capacity over the experimental cycles, which is attributed to biosorbent saturation affecting the number of available sites for heavy metal uptake $^{14}$. At the end of the third cycle, removal yield was reduced by $30 \%$ suggesting a short useful life for this biomass. In addition, these results can be also explained by the effects of desorbing agents on the biosorbent that are employed to prepare the biomass for other adsorption cycle ${ }^{21}, \underline{22}$ reported a reduction in removal yield around $13.3 \%$ after ten adsorption cycles using activated carbon for copper ions removal.

The desorption process was performed through nitric acid solution, which reported to be non-viable because of the low desorption yield results shown in Figure 9. $\operatorname{In}^{23}$ also used this desorbing agent for $\mathrm{Cr}(\mathrm{VI})$ ions desorption from Spirulina sp. and obtained desorption yield of $98 \%$. $\mathrm{In}^{24}$ pointed out that hexavalent chromium adsorption is an irreversible process due to traces of desorbed metal are insignificant and are not affected by the increase in acid concentration. $\mathrm{In}^{25}$ reported $\mathrm{Cr}(\mathrm{VI})$ ions desorption yield of $98 \%$ using mixtures of sodium hydroxide and sodium chloride.

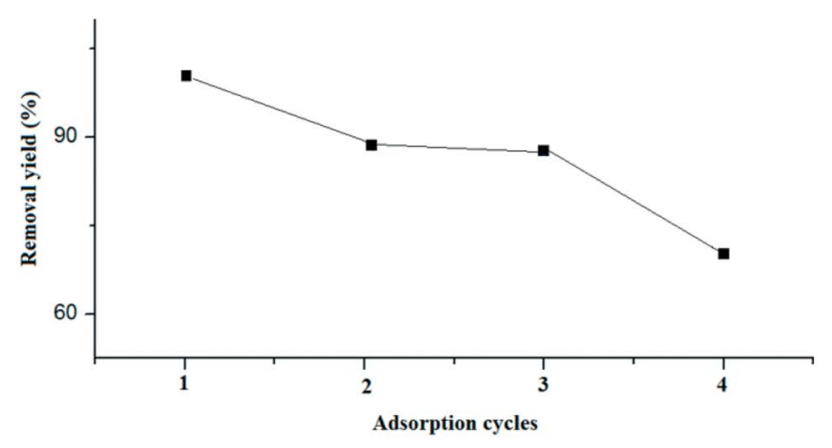

Figure 8. Effect of adsorption cycles on removal yield.

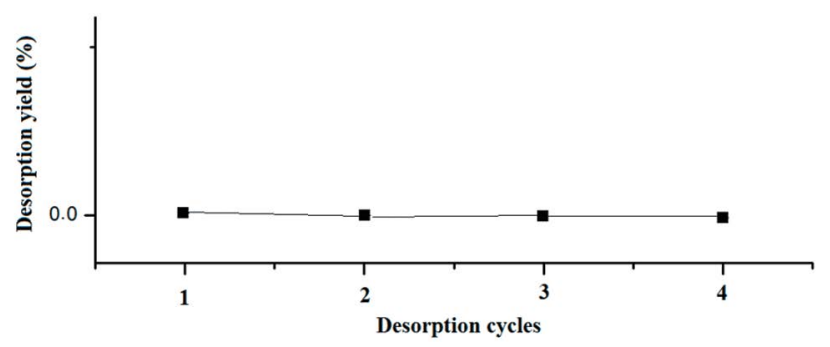

Figure 9. Desorption experimental results. 
Table 1. Mechanical resistance of bricks

\begin{tabular}{lllllll}
\hline & & \multicolumn{2}{l}{ Rupture force } & & \multicolumn{2}{c}{ Mechanical resistance } \\
\cline { 3 - 4 } \cline { 6 - 7 } Biomass (\%) & Area $\left(\mathrm{cm}^{2}\right)$ & $\mathbf{l b}_{\mathrm{f}}$ & $\mathrm{Kg}_{\mathrm{f}}$ & & $\mathbf{K g f} / \mathrm{cm}^{2}$ & Mpa \\
\hline $\mathbf{5}$ & 25 & 1739.743 & 789.133507 & & 31.5653403 & 3.09550244 \\
7.5 & 25 & 1584.4012 & 718.671709 & & 28.7468684 & 2.81910477 \\
$\mathbf{1 0}$ & 25 & 876.733 & 397.679075 & & 15.907163 & 1.5599598 \\
\hline
\end{tabular}

Table 2. Results for leaching tests

\begin{tabular}{ll}
\hline Biomass (\%) & Leachateconcentration (ppm) \\
\hline $\mathbf{5}$ & 0.09009 \\
7.5 & 0 \\
\hline 10 & 0.9009 \\
\hline
\end{tabular}

\subsection{Solidification/Stabilization Immobilization Technique}

The bricks were prepared by mixing clay with polluted biosorbent (5, 7.5 and $10 \%$ of biomass). The mechanical resistance testing was performed using Soiltest Universal Machine. Table 1 summarizes the results obtained during these experiments. It was found that the bricks with 5 and $7.5 \%$ of biomass obeyed the quality standard of 3-14 MPa reported in the regulation NTC 4017 (Nov. 2005) ${ }^{26}$. The leaching experiments were performed to evaluate the efficiency of solidification/stabilization technique for encapsulating heavy metal ions. As listed in Table 2, the leachate concentrations for all bricks were below $5 \mathrm{mg} / \mathrm{L}$, which is the limit value reported by national environmental regulation (Decree 4741/2015) ${ }^{27}$.

\section{Conclusions}

The solidification/stabilization immobilizationtechnique was applied to encapsulate hexavalent chromium ions in bricks containing polluted banana peels biomass, which obeyed environmental and quality standards. The characterization of banana peels biomass indicated the presence of hydroxyl and carbonyl groups that are recognized to enhance adsorption process.

The biosorbent dosage was identified as the parameter that most affects $\mathrm{Cr}$ (VI) ions uptake. The adsorption kinetics reported better results at $25^{\circ} \mathrm{C}, 0.5 \mathrm{~mm}$ and $0.67 \mathrm{~g}$ of temperature, particle size and biosorbent dosage, respectively. During adsorption-desorption cycles, the biomass reduced its removal capacity by $30 \%$. The bricks prepared with clay and polluted biomass exhibited good resistance to compression above the quality standard using 5 and $7.5 \%$ of biomass. For all bricks, leaching test showed leachate concentration below the environmental regulation indicating the suitability of this heavy metal encapsulation alternative from an environmental viewpoint.

\section{Acknowledgement}

Author is grateful to University of Cartagena for supporting this work.

\section{References}

1. Jobby R, Jha P, Yadav A, Desai N. Biosorption and biotrans formation of hexavalent chromium [Cr(VI)]: A comprehensive review. Chemosphere. 2018; 207:255-66. https://doi.org/10.1016/j.chemosphere.2018.05.050 PMid:29803157

2. Sriram S, Nambi I, Chetty R. Electrochemical reduction of hexavalent chromium on titania nanotubes with urea as ananolyte additive. Electrochimica Acta. 2018, 284, pp. 427-435. https://doi.org/10.1016/j.electacta.2018.07.194

3. $\mathrm{Yu} \mathrm{X}, \mathrm{Yu} \mathrm{R}$, Gui D. Hexavalent chromium induces oxidative stress and mitochondria-mediated apoptosis in isolated skin fibroblasts of Indo-Pacific hump back dolphin. Aquatic Toxicology. 2018; 203:179-86. https://doi.org/10.1016/j.aquatox.2018.08.012 PMid:30153559

4. Vakili M, Deng S, Li T, Wang W, Wang W, Yu G. Novel cross linked chitosan for enhanced adsorption of hexavalent chromium in acidic solution. Chemical Engineering Journal. 2018; 347:782-90. https://doi.org/10.1016/j.cej.2018.04.181

5. Guo B, Liu B, Yang J, Zhang S. The mechanisms of heavy metal immobilization by cementitious material treatments and thermal treatments: A review. Journal of Environmental Management. 2017; 193:410-22. https://doi.org/10.1016/j.jenvman.2017.02.026 PMid:28238544 
6. Herrera-Barros A, Tejada-Tovar C, Villabona-Ortiz A, Gonzalez-Delgado A, Fornaris-Lozada L. Effect of $\mathrm{pH}$ and particle size for lead and nickel uptake from aqueous solution using cassava (Manihot esculenta) and yam (Dioscoreaalata) residual biomasses modified with titanium dioxide nanoparticles. Indian Journal of Science and Technology. 2018; 11(21):1-7. https://doi.org/10.17485/ijst/2018/v11i21/123250

7. Pacheco-Perez K, Baia-Olivares M, MezaGonzalez D, Gonzalez-Delgado AD. Exergy analysis of hydrogen production from palm oil solid wastes using indirect gasification. Indian Journal of Science and Technology. 2018; 11(2):1-6. https://doi.org/10.17485/ijst/2018/v11i2/120429

8. Mahindrakar K, Rathod V. Utilization of banana peels for removal of strontium (II) from water. Environmental Technology and Innovation. 2018; 11:371-83. https://doi.org/10.1016/j.eti.2018.06.015

9. Tejada-Tovar C, Villabona-Ortíz A, Herrera-Barros A, González-Delgado ÁD, Garcés L. Adsorption kinetics of $\mathrm{Cr}$ (VI) using modified residual biomass in batch and continuous system. Indian Journal of Science and Technology. 2018; 11(14):1-8. https://doi.org/10.17485/ijst/2018/v11i14/121782

10. Singh S, Parveen N, Gupta H. Adsorptive decontamination of rhodamine-B from water using banana peel powder: A biosorbent. Environmental Technology and Innovation. 2018; 12:189-195. https://doi.org/10.1016/j.eti.2018.09.001

11. Vu H, Scarlett C, Voung Q. Phenolic compounds within banana peel and their potential uses: A review. Journal of Functional Foods. 2018; 40:238-48. https://doi.org/10.1016/j.jff.2017.11.006

12. Lara J, Tejada-Tovar C, Villabona-Ortíz A, Arrieta A. Adsorción de plomo y cadmio en sistema continuo de lecho fijo sobre residuos de cacao (Adsorption of lead and cadmium in continuous of fixed bed on cocoa waste) (Adsorção de chumbo e cádmio no sistema de leitofixocontínua relativa aosresíduos de cacau). Revista ION. 2016; 29:1-13.

13. Tejada-Tovar C, Villabona-Ortiz A, Ruiz-Paternina E. Remoción de $\mathrm{Pb}$ (II), Ni (II) y Cr (VI) en soluciones acuosas usando matrices modificadas químicamente. Prospectiva. 2014; 12(2):7-17. https://doi.org/10.15665/rp.v12i2.265

14. Mata $\mathrm{Y}$, Blázquez $\mathrm{M}$, Ballester $\mathrm{A}$, González F, Mu-oz J. Studies on sorption, desorption, regeneration and reuse of sugar-beet pectin gels for heavy metals removal. Journal of Hazardous Materials. 2010; 178:243-8. https://doi.org/10.1016/j.jhazmat.2010.01.069 PMid:20122797
15. Ngo H, Abdolali A, Wenshan G. Characterization of a multi-metal binding biosorbent: Chemical modification and desorption studies. Bioresource Technology. 2015; 193:477-87. https://doi.org/10.1016/j.biortech.2015.06.123 PMid:26162526

16. Arsenovic M, Radojevic Z, Stankovic S. Removal of toxic metals from industrial sludge by fixing in brick structure. Construction and Building Materials. 2012; 37:7-14. https://doi.org/10.1016/j.conbuildmat.2012.07.002

17. Ukwatta P, Mohajerani A. Effect of organic content in biosolids on the properties of firedclay bricks incorporated with biosolids. Journal of Materials in Civil Engineering. 2017; 29(7):1-11. https://doi.org/10.1061/(ASCE)MT.1943-5533.0001865

18. Tejada-Tovar C, Tejeda L, Marimón W, Villabona-Ortíz A. Estudio de modificación química y física de biomasa (Citrus sinensis y Musa paradisiaca) para la adsorción de metales pesados en solución. Revista Luna Azul. 2014; 39:124-42. https://doi.org/10.17151/luaz.2014.39.8

19. Velasco S. Remoción de plomo presente en soluciones acuosas mediante adsorción con residuos del plátano Musa AAB Simonds. Universidad Libre; 2014. p. 1-58.

20. Eggs N, Salvarezza S, Azario R, Fernández N, García M. Adsorcioón de cromo hexavalente en la cáscara de arroz modificada químicamente. Avances en Ciencias e Ingeniería; 2010. p. 141-51.

21. Armas E, Guevara A. Biosorción de cromo total en soluciones ideales utilizando una matriz de mircroalgas nativas inmovilizadas en alginato cálcico. D Space Repository; 2017.

22. Da'na E, Awad A. Regeneration of spent activated carbon obtained from home filtration system and applying it for heavy metals adsorption. Journal of Environmental Chemical Engineering. 2017; 5(4):3091-9. https://doi.org/10.1016/j.jece.2017.06.022

23. Chonjnacka K, Chonjnacki A, Górecka H. Biosorption of $\mathrm{Cr} 3+, \mathrm{Cd} 2+$ and $\mathrm{Cu} 2+$ ions by blue-green algae Spirulin asp.: kinetics, equilibrium and the mechanism of the process. Chemosphere. 2005; 59(1):75-84. https://doi.org/10.1016/j.chemosphere.2004.10.005 PMid:15698647

24. Rodríguez R, Linares R, Guadalupe E. Adsorción y desorción de cromo hexavalente en relaves mineros. Revista del Instituto de Investigación de la Facultad de Ingeniería Geológica, Minera, Metalurgica y Geográfica. 2009; 12(24):1-9.

25. Díaz C, Jacinto C, Medina R, Navarro A, Cuizano N, Llanos B. Estudio de la biosorcion de cromo (VI) con quitosano cuaternario reticulado para su aplicación en 
biorremediación de aguas contaminadas. Revista de la Sociedad Química del Perú. 2013; 79:304-18.

26. NTC. 4017: Métodos Para Muestreo Y Ensayos de Unidades de Mampostería Y Otros Productos de Arcilla. Available from: https://www.libreriadelau.com/ ntc-4017-metodos-para-muestreo-y-ensayos-de-unidadesde-mamposteria-y-otros-productos-de-arcilla-icontecnull-ingenieria-civil/p
27. Ministerio de Ambiente. Decreto 4741 de 2005: Por El Cual Se Reglamenta Parcialmente La Prevención Y Manejo de Los Residuos O Desechos Peligrosos Generados En El Marco de La Gestión Integral. Available from: http://www. ideam.gov.co/documents/51310/526371/Decreto+4741+2 005+PREVENCION+Y+MANEJO+DE+REIDUOS+PEL IGROSOS+GENERADOS+EN+GESTION+INTEGRAL. pdf/491df435-061e-4d27-b40f-c8b3afe25705 